\title{
Legitimação não Tradicional da Ação Penal - A Tutela de Bens Jurídicos por outras Instituições Públicas
}

\author{
Non traditional legitimation for criminal action - \\ legal protection of goods from other public institutions
}

Franklyn Roger Alves Silva ${ }^{1}$

Doutorando e Mestre em Direito Processual pela UERJ. Professor Auxiliar na Universidade Cândido Mendes (Rio de Janeiro/RJ). franklyn.roger@gmail.com

http://lattes.cnpq.br/7268807770125558

http://orcid.org/0000-0002-4863-3507

\begin{abstract}
Resumo: O presente artigo examina a questão atinente ao exercício da legitimidade da ação penal de forma supletiva por outras instituições públicas quando houver a violação de direitos transindividuais penais e a inércia do Ministério Público. Nas infrações com sujeito passivo indeterminado, falta previsão legal para a incidência da ação penal privada subsidiária. Nesta perspectiva, investigam-se outros dispositivos legais que permitam identificar uma alternativa à iniciativa acusatória. Ao mesmo tempo, verifica-se a aptidão da Defensoria Pública para o exercício desta legitimação supletiva.

Palavras-chave: Legitimidade; Ação Penal; Coletividade; Defensoria Pública.
\end{abstract}

ABSTRACT: This article examines the question regards the legitimacy of the prosecution in a supplementary manner from of other public institutions to promote when facing violation of criminal transindividual rights and inertia of the prosecution. When facing crimes with an indeterminate passive subject, there is lack of legal support to base a subsidiary criminal action. Over this perspective, it is investigated if there are other laws

1 Doutorando e Mestre em Direito Processual pela Universidade do Estado do Rio de Janeiro - UERJ. Professor Auxiliar na Universidade Cândido Mendes (Centro - Rio de Janeiro/RJ). Defensor Público do Estado do Rio de Janeiro. 
allowing an alternative legitimacy for criminal charges. At the same time, it is verified the Public Defender's Office ability to exercise the supplementary legitimacy.

Keywords: Legitimacy; Criminal Action; Transindividual Rights; Public Defender`s Office.

SUMÁRIO: Introdução; I - Os instrumentos de legitimação subsidiária para a ação penal; II - A defesa de bens jurídicos pelas pessoas jurídicas de direito público interno nos chamados "crimes vagos"; III - O papel de proteção de direitos transindividuais conferido à Defensoria Pública e às pessoas jurídicas de direito público; Conclusão; Referências.

\section{INTRODUÇÃO}

O advento do novo Código de Processo Civil despertou profícuas discussões no campo adjetivo civil, especialmente pelas inovações trazidas em seu corpo, a exemplo do sistema brasileiro de precedentes e da adaptabilidade procedimental decorrente das convenções processuais.

Esta tendência não é encontrada no processo penal que ainda resiste em debater e revisitar temas clássicos - o que não é inadequado, desde que não se deixe de olhar para as novidades do direito processual e considere a possibilidade de modernização a partir destes paradigmas.

O foco do presente artigo se direciona para o estudo da ação penal e como o instituto pode ser reinterpretado, especialmente em relação aos crimes de iniciativa pública incondicionada, quando levadas em consideração as novas perspectivas normativas trazidas pelo ordenamento jurídico.

O exercício da pretensão e a tutela cautelar são temas de grande preocupação no direito processual penal brasileiro, especialmente em virtude das graves consequências advindas da instauração da ação penal e da restrição ao direito de liberdade à esfera do indivíduo.

A importância da persecução penal se extrai do reconhecimento doutrinário de uma quarta condição para o regular exercício do direi- 
to de ação $0^{2}$, restrita ao processo penal, referente à exigência do suporte probatório mínimo, a chamada justa causa ${ }^{3}$.

Essa quarta condição da ação, expressamente referenciada pelo art. 395, III do CPP exige que a deflagração da ação penal seja permeada por atos de investigação praticados pelos órgãos oficiais com o objetivo de demonstrar ao Judiciário os indícios do crime e de sua autoria.

Ainda tratada por muitos como condição da ação penal ${ }^{4}$, a justa causa é uma forma de condicionamento do regular exercício da deman-

2 Na doutrina há quem amplie o rol de condições para o regular exercício do direito de ação, a exemplo de Afrânio Silva Jardim e a exigência de originalidade: "Quando falamos em originalidade, estamos querendo dizer o mesmo direito de ação não pode ser exercido simultaneamente (litispendência), ou mesmo, sucessivamente (se houver coisa julgada material). Vale dizer, não litispendência e não violação à coisa julgada. A ação tem de ser original e não uma "cópia" de outra ainda pendente ou já constante de outro processo apreciado no mérito.” (JARDIM, Afrânio Silva; AMORIM, Pierre Souto Maior Coutinho de. Direito processual penal: estudos e pareceres. 14. Ed. Salvador: Juspodivm, 2016. p. 90).

3 Indique-se também o posicionamento de Tourinho Filho (TOURINHO FILHO, Fernando da Costa. Processo penal. 29. Ed. São Paulo: Saraiva, 2007. p. 533) e Badaró (BADARÓ, Gustavo Henrique. Correlação entre acusação e sentença. São Paulo: RT, 2000. p. 83) a respeito da exigência do "fato aparentemente criminoso - fumus commissi delicti": "Por fim, a exigência de que a acusação demonstre a verossimilhança da tipicidade, antijuridicidade e culpabilidade também decorre da exigência constitucional da Proporcionalidade, vista com proibição de excesso de intervenção, em que o custo social e jurídico do processo penal fazem com que ele não se contente com a mera tipicidade se for manifesta a presença de uma causa de exclusão da ilicitude ou da culpabilidade.” (LOPES JR., Aury. Direito processual penal. 11. Ed. São Paulo: Saraiva, 2014. p. 373).

4 É importante levar em conta a rica discussão da subsistência das condições da ação no direito processual civil: "O silêncio normativo a respeito da categorização das condições da ação levantou interessante discussão teórica. Humberto Dalla, Leonardo Greco, Daniel Neves e Alexandre Câmara, reputam que o trinômio pressupostos processuais - condições da ação - mérito, subsiste no sistema processual civil brasileiro mesmo diante do silêncio normativo. Sinteticamente, o fato de se continuar a prestigiar a teoria da asserção seria uma advertência legislativa de que as condições da ação permaneceriam vivas no sistema processual. Ademais, a legitimidade e o interesse seriam requisitos intrínsecos ao exercício regular do direito de ação, segundo a teoria eclética de Liebman, pouco importando que o novo CPC tenha se silenciado acerca de sua natureza jurídica. Esta, no entanto, não é a opinião de Fredie Didier Jr., Alexandre Flexa, Daniel Macedo, Fabrício Bastos e Leonardo 
da a uma demonstração perfunctória dos indícios de materialidade e autoria, visando evitar a utilização do direito de ação com fins casuísticos e obscuros, um verdadeiro "filtro persecutório"

Modernamente, enxerga-se na justa causa a natureza de pressuposto legitimador do processo penal condenatório ${ }^{6}$, já que o CPP refere-se a ela em passagem diversa das condições da ação. Apesar de originada da leitura da regulamentação do Habeas Corpus, há também a proposição teórica da justa causa como um instrumento de política criminal (instituto não mais restrito ao direito processual), centrada na análise da eficiência da persecução penal diante da ofensividade da conduta praticada e na adequação da intervenção estatal ${ }^{7}$.

Esse avanço das reflexões a respeito das consequências do exercício do direito de ação é tamanho que o Direito Processual Civil começa a discutir a possibilidade de exigir o suporte probatório mínimo em suas demandas. A consistência da pretensão deduzida ${ }^{8}$, especialmente quando a demanda civil repercute em esferas tão importantes da pessoa

Cunha. Para estes autores, a opção legislativa foi a de suprimir a categorização autônoma das condições da ação. Dentro desta perspectiva, importante considerar a existência de certo dissenso, já que haveria aquele que enquadra a legitimidade e o interesse na categoria de pressupostos processuais (Didier Jr.) e outro que os enxerga como questões de mérito (Leonardo Cunha)." (SILVA, Franklyn Roger Alves. Os efeitos do novo código de processo civil no direito processual penal: um feixe de luz para o caminho da sofisticação ou a permanência na escuridão? Revista Forense, vol. 423, 2016. p. 48-49).

5 DIVAN, Gabriel Antinolfi. Processo penal e política criminal: uma reconfiguração da justa causa para a ação penal. Porto Alegre: Elegantia Juris, 2015. p. 320.

6 Importante advertir a atual reconstrução teórica proposta por Afrânio Silva Jardim no sentido de enxergar a justa causa não como condição da ação penal, mas como pressuposto de legitimação do processo penal condenatório. (JARDIM, Afrânio Silva; AMORIM, Pierre Souto Maior Coutinho de. Direito processual penal: estudos e pareceres. 14. Ed. Salvador: Juspodivm, 2016. p. 585).

7 DIVAN, Gabriel Antinolfi. Op. cit. p. 502.

8 "A meu ver, todavia, para evitar-se a autolegitimação não há necessidade de recorrer a uma quarta ou a uma quinta condição da ação. Considero que a consistência de agir, ou seja, para evidenciar a necessidade do autor de recorrer à jurisdição. Essa necessidade pressupõe uma hipótese verossímil, viável e minimamente fundamentada em fatos provas." (GRECO, Leonardo. Instituições de processo civil. 5. Ed. Rio de Janeiro: Forense, 2015. p. 225). 
natural ou jurídica, a exemplo das ações de improbidade administrati$v^{9}{ }^{9}$, é um tema que está na pauta processual civil.

A Constituição da República, o Código de Processo Penal e algumas leis esparsas tratam das diferentes modalidades de ação penal. No entanto, em relação aos denominados crimes vagos (sujeito passivo indeterminado), a legitimidade da ação penal se restringe ao Ministério Público, não havendo uma válvula de escape apta a persecução destas infrações no caso de inércia de atuação do órgão ministerial.

Seria intenção do nosso sistema jurídico realmente restringir ao Ministério Público a tutela de bens jurídicos afetos à coletividade, levando em consideração a sua função constitucional de defesa da ordem jurídica? Haveria espaço para o reconhecimento de uma legitimação supletiva para a promoção da ação penal?

Admitindo-se a existência desta legitimidade, quem teria aptidão para provocar o Poder Judiciário mediante deflagração da ação penal? Outras instituições públicas destinadas à defesa da coletividade poderiam exercer a defesa supletiva de bens jurídicos difusos, coletivos e de direitos humanos?

Nossa história tem revelado que a concentração de poderes nas mãos de um ou poucos atores do processo ${ }^{10}$ nem sempre significa a adequada tutela, o que torna necessária a diluição de responsabilidades.

9 "Vê-se, pela leitura do dispositivo, que o ajuizamento da petição inicial sem a observância deste comando pode levar a que se considere o demandante litigante de má-fé. É, pois, absolutamente essencial que a inicial venha acompanhada de provas mínimas da existência do ato de improbidade administrativa, ou de razões fundamentadas para que se reconheça a impossibilidade de sua apresentação nesse momento processual. Como regra geral, pois, a petição inicial terá de vir acompanhada de um mínimo de prova da existência do ato de improbidade administrativa. Isto tem levado a doutrina especializada a afirmar que a "ação de improbidade administrativa" estaria sujeita a uma "condição específica da ação", que normalmente não se exige nos processos não-penais: a "justa causa”. (CÂMARA, Alexandre Freitas. A fase preliminar do procedimento da ação de improbidade administrativa. Disponível em: https://www.academia.edu/375133/A_fase_preliminar_do_procedimento_ da_ação_de_improbidade_administrativa. Acesso em: 13 jun 2016. p. 4).

10 Dentre os inúmeros argumentos utilizados pelo Ministério Público para o desempenho da investigação criminal direta era justamente o de evitar o corporativismo das Polícias Judiciárias. 
Prevendo o sistema jurídico processual alternativas ao exercício do direito de ação penal pública, a suficiência destes instrumentos está a merecer uma investigação mais aprofundada, especialmente quando levados em consideração os direitos humanos e os direitos penais difusos e coletivos ${ }^{11}$.

Sistematizar as ações penais no direito processual penal brasileiro e identificar soluções para o caso de inércia do Ministério Público nas hipóteses em que o sujeito passivo de determinada infração penal é indeterminado, ou seja, a coletividade, é o primeiro passo desta reflexão.

O norte de investigação consistirá no fundamento da dignidade da pessoa humana (art. $1^{\circ}$, III da CRFB), nos objetivos constitucionais previstos no art. $3^{\circ}$ (construir uma sociedade, livre, justa e solidária; redução das desigualdades sociais e regionais, promoção do bem de todos, sem preconceitos de origem, raça, sexo, cor, idade e quaisquer outras formas de discriminação), na garantia de inviolabilidade do direito à vida, à liberdade, à igualdade, à segurança e à propriedade (art. $5^{\circ}$ da CRFB) e nos deveres de prestação estatal que atingem a coletividade.

11 É interessante destacar a característica do monopólio do direito de ação no processo penal italiano. A doutrina aponta que a Corte de Cassação Italiana já decidiu que a legitimidade da ação penal é restrita ao Ministério Público, à exceção dos procedimentos perante o juiz de paz, quando se estende ao ofendido, mas assevera que uma norma que ampliasse a legitimação para outro sujeito seria legítima: "O monopólio da ação penal em poder do Ministério Público não é imposto pela Carta Fundamental. O art. 112 da Constituição atribui ao Ministério Público o dever de exercer a ação penal; Não prescreve que esta última seja exercitada, somente por um órgão público. Assim, tanto nos trabalhos preparatórios da constituição e, em particular, da própria exclusão de uma emenda que tendia a qualificar como pública a ação penal. A Corte Constitucional (Sentença n. 84 de 1979) afirmou que a titularidade da ação penal pode ser conferida também a sujeitos diversos do Ministério Público para seu exercício, mesmo diante do Código de Processo Penal que tenha atribuído unicamente ao Ministério Público o poder de exercitar a ação penal (art. 405). Tal poder não foi conferido nem a vítima. Se trata de uma escolha do legislador ordinário." (TONINI, Paolo. Manuale di procedura penale. Milano: Giuffrè. 2009. p. 521) (tradução livre). 


\section{I - OS INSTRUMENTOS DE LEGITIMAÇÃO SUBSIDIÁRIA PARA A AÇÃO PENAL}

Para falarmos sobre ação penal no direito brasileiro é indissociável a prévia e breve reflexão a respeito da existência de uma teoria geral do direito processual, inconfundível com as inúmeras teorias difundidas que espelham, em verdade, uma teoria da parte geral do Código de Processo Civil.

Apesar de não termos um trabalho doutrinário capaz de sistematizar essa teoria geral, a nosso ver é possível enxergá-la, principalmente em virtude dos pontos de interseção entre o processo civil e o processo penal (jurisdição, ação, procedimentos, nulidades etc.) ${ }^{12}$. A teoria geral estaria um nível acima ao direito positivado e estabeleceria premissas comuns a todos os ramos do processo ${ }^{13}$.

A previsão de procedimentos, as regras de nulidade ${ }^{14}$, a existência de pressupostos processuais, as características da jurisdição, a divisão de encargos entre os sujeitos do processo demonstram a possibilidade de se traçar uma teoria geral que dialogaria com as normas

12 “Como já adiantamos, o estudo das nulidades, em nosso entender, corresponde a um tema de teoria geral do processo, e pode ser definido e teorizado uniformemente para todas as suas espécies: civil, penal, trabalhista, administrativo. Somos favoráveis à existência de uma teoria geral do processo e estamos convencidos de que, em especial no tema das nulidades, existe um núcleo comum que pode ser analisado em conjunto." (CABRAL, Antonio do Passo. Nulidades no processo moderno. Rio de Janeiro: Forense, 2009. p. 350).

13 “Assim, a noção de teoria geral do processo me parece menos restritiva que a referência ao direito processual como é definida hoje em termos de evolução que vem a ser descrito. Certamente, como escreve Raymond Martin, a comparação pode servir a teoria geral, que se situa em um degrau de elaboração superior ao nível da comparação, mas a comparação não é uma condição da teoria geral. A teoria geral não pode nem menos reduzi-la. Ela oferece, então, mais flexibilidade que a lei processual." (CADIET, Loïc. Prolégomènes à une théorie générale du procès en droit français. In: DIDIER JR., Fredie; JORDÃO, Eduardo Ferreira (Org.). Teoria do processo: panorama doutrinário mundial. Salvador: Juspodivm, 2008. p. 492) (tradução livre).

14 "A existência ou não de nulidades relativas no processo é tema da Teoria Geral do Processo, que deve atentar para as peculiaridades do processo civil, penal e do trabalho. Aliás, a teoria das nulidades dos atos jurídicos é tema da própria Teoria Geral do Direito.” (JARDIM, Afrânio Silva; AMORIM, Pierre Souto Maior Coutinho de. Direito processual penal: estudos e pareceres. 14. Ed. Salvador: Juspodivm, 2016. p. 77). 
processuais e ao mesmo tempo revelaria sua aptidão para a construção e o reforço da sistematização processual em todos os seus ramos.

Os refratários da teoria geral do processo ${ }^{15}$ tendem a qualificar o objeto do processo penal como se se tratasse da tutela do bem jurídico mais relevante do ordenamento jurídico, o que significaria a sua autonomia, dada a importância da pretensão que lá se veicula.

Apesar de reconhecer a importância da dogmática processual penal, cremos que o referencial dos separatistas desconsidera o objeto do processo civil, querendo fazer crer que o seu propósito é a tutela das questões triviais e das demandas patrimoniais disponíveis, desprestigiando a sua importância para o trato de temas tão ou mais importantes que a liberdade.

Independentemente da discussão a respeito da existência ou não de lide $^{16}$ e dos interesses tutelados por ambas as disciplinas, fato é

15 “O processo civil é o cenário da riqueza (de quem possui), ao passo que no processo penal, cada vez mais, é o processo de quem não tem, do excluído. Isso contribui para o estigma da gata borralheira, mas não justifica. No processo penal, em (radical) câmbio, do que estamos tratando? Não é do ter, mas sim da liberdade. No lugar de coisa, pensa-se na liberdade, de quem, tendo, está na iminência de perder, ou que já não tendo pode recuperá-la ou perdê-la ainda mais. Trata-se de voltar para casa ou ser encarcerado. Como adverte CARNELUTTI, é com a liberdade o que verdadeiramente se joga no processo penal. Al juez penal se le pide, como al juez civil, algo que nos falta y de lo cual no podemos prescindir; y es mucho más grave el defecto de libertad que el defecto de propriedade." (LOPES JR., Aury. Direito processual penal. 11. Ed. São Paulo: Saraiva, 2014. p. 59).

16 "Já se assentou, há algum tempo, que o conceito de lide é muito mais sociológico que jurídico e sempre se mostrou insuficiente para caracterizar o fenômeno processual, mormente porque continua impregnado de uma visão ultrapassada, que põe o processo como mera extensão do direito material, um palco para fazer valer pretensões descumpridas nas relações entre particulares. Amarrar o objetivo do processo apenas à resolução da lide não realça adequadamente os escopos do processo (social, político e jurídico), que transcendem (e muito) os interesses privados eventualmente em conflito. Ademais, CARNELUTTI admitiu em dado momento que houvesse casos excepcionais de "processo sem lide", como nos feitos de jurisdição voluntária (o exemplo acatado por CARNELUTTI é a anulação de casamento, pleiteada conjuntamente por marido e mulher), ou quando o devedor reconhece juridicamente a pretensão do credor (deixando de resistir a ela). Ou seja, mesmo CARNELUTTI reconheceu, indiretamente, a insuficiência do conceito de lide para caracterização do fenômeno processual.” (SICA, Heitor Vitor 
que o processo civil e processo penal possuem estruturação semelhan$\mathrm{te}^{17}$ em diversos aspectos, o que reforça a opinião que compartilhamos quanto a existência da teoria geral do direito processual ${ }^{18}$.

A teoria geral do processo tem o papel de construir as linhas mestras comuns aos diferentes ramos do processo, como adverte Tourinho Filho ${ }^{19}$ e permitir a devida aplicação do direito processual, nas palavras de Didier Jr ${ }^{20}$.

Talvez o grande obstáculo a incorporação da teoria geral no pensamento comum seja o fato de que ela ainda não foi adequada e su-

Mendonça. Perspectivas atuais da teoria geral do processo. In: CARNEIRO, Athos Gusmão; CALMON, Petrônio (Org). Bases científicas para um renovado direito processual. Brasília: IBDP, 2008, v. 1, p. 39-66).

17 "O direito processual civil como ramo que do mesmo tronco disciplinar, com comunhão de princípios gerais com o direito processual penal, faz com que este possa se integrar em muitos dos seus institutos...” (COMPAREID, Carlos Roman; SANTAGATI, Claudio Jesús. Manual de derecho procesal penal. Buenos Aires: Ediciones Juridicas, 2010. p. 58).

18 "O direito Processual Penal é ciência jurídica que se liga ao Direito Processual Civil, por constituírem ambos divisão do Direito Processual e se filiarem um e outro à teoria geral do processo. No Direito Processual Civil, foi o Direito Processual Penal colher os institutos necessários para a processualização da Justiça Penal, após ter sido adotado o sistema acusatório. (...) Filho primogênito da ciência jurídica do processo, coube, portanto ao Direito Processual Civil a tarefa de construir as linhas matrizes do processo em geral, formulando-lhe os conceitos estruturais e enunciando-lhe os princípios básicos. Ali nasceram, por isso, institutos fundamentais do processo em geral, e ali recebeu este a sua configuração essencial de actum trium personarum, como instrumento de Estado para compor litígios e dar a cada um o que é seu. (...) Quando se afirma a unidade do Direito Processual, não se está admitindo que processo civil e processo penal sejam idênticos, mas tão-só mostrando que ambos têm base comum, que é a teoria geral do processo, teoria que pode e deve ser elaborada por exigência científica de elementar evidência, como bem afirmou GRISPIGNI." (MARQUES, José Frederico. Manual de direito processual civil. Campinas: Bookseller, 1997. Vol. I. p. 48-51).

19 “O processo, como instrumento compositivo do litígio, é um só. É por meio do processo que o Estado desenvolve sua atividade jurisdicional. Assim, o Direito Processual Civil e Direito Processual Penal não passam de faces de um mesmo fenômeno, ramos de um mesmo tronco que cresceu por cissiparidade." (TOURINHO FILHO, Fernando da Costa. Processo penal. 29. Ed. São Paulo: Saraiva, 2007. p. 19).

20 DIDIER JR., Fredie. Sobre a teoria geral do processo, essa desconhecida. 3.ed. Salvador: Juspodivm, 2016. p. 127. 
ficientemente categorizada, permanecendo em um ambiente de névoas, impedindo a comunidade processual de compreendê-la.

Partindo para o campo do direito de ação, nota-se que o processo penal brasileiro trabalha com dois grandes blocos de ação penal. De um lado, a regra geral reflete o exercício da ação penal de iniciativa pública, com titularidade privativa do Ministério Público (arts. 129, I da CRFB e 24 do CPP).

Nesta primeira categorização da ação penal aponta-se a indisponibilidade do bem jurídico atingido, o que significa dizer que a vontade ou autorização da vítima é irrelevante para a persecução penal. A gravidade da conduta e o ataque ao bem jurídico demandam adequada proteção do Estado nos crimes apurados por meio de uma ação penal de iniciativa pública incondicionada.

No entanto, há que se observar, dentro da perspectiva da ação penal pública, que tanto o Código Penal como o Código de Processo Penal reconhecem um rol de crimes que, a despeito de serem processados por meio de ação iniciada pelo Ministério Público, dependem de uma prévia manifestação do ofendido (representação) ou do Ministro da Justiça (requisição). ${ }^{21}$

Nas chamadas ações penais de iniciativa pública condicionada, sua existência deriva do fato de que o legislador considera, por conta do equilíbrio entre a gravidade do crime e o desejo da vítima em ver apurado o fato criminoso, que esta última manifestação de vontade seja uma condicionante à averiguação do fato criminoso.

Em outro plano do direito de ação, também há o reconhecimento da legitimação conferida ao particular - rectius ofendido - para iniciar e dar continuidade à ação penal de caráter privado nas infrações

21 O Direito Português também possui estruturação semelhante, quando observados os chamados crimes público e semi-públicos: "Nos crimes públicos, o MP, depois de tomar conhecimento da notícia do crime, promove, obrigatória e oficiosamente, o processo penal, dando início à fase do inquérito... Depois de proceder às diligências de investigação, o MP decide, com plena autonomia, se o arguido deverá ou não ser submetido a julgamento. (...) Nos crimes semi-públicos, a promoção do processo penal por parte do MP está dependente da apresentação de queixa por parte do ofendido ou de outras pessoas a quem a lei confere esse direito..." (CARVALHO, Paula Marques. Manual prático de processo penal. 8. Ed. Almedina: Coimbra, 2014. p. 42). 
penais de menor gravidade (art. 30 do CPP), sem que isso desnature ${ }^{22} \mathrm{o}$ caráter público subjetivo ${ }^{23}$ do direito de ação $0^{24}$.

Se é verdade que o sistema processual atribuiu a exclusividade da ação penal pública ao Ministério Público, também o é a real preocupação do legislador em estabelecer mecanismos de controle aos poderes concentrados nas mãos do órgão ministerial.

Como já advertia Frederico Marques "o Ministério Público não é o proprietário da ação penal e, sim o seu agente" 25 . A titularidade do direito de ação não estaria acompanhada de eventual discricionariedade para a sua deflagração, diante do seu caráter obrigatório e indisponível.

A função anômala do juiz no arquivamento do inquérito policial ${ }^{26}$, a ação penal de iniciativa privada subsidiária e as construções

22 Acreditamos que o direito de ação ostenta natureza pública, por significar o ato de solicitar ao estado-juiz a prestação jurisdicional. A ação não se confunde com o processo e nem com a legitimação. O fato de se atribuir legitimidade ao particular não desnatura a natureza pública do instituto, já que ele também a detém para o ajuizamento de ação coletiva (cidadão e associações) e nem por isso cogita-se uma natureza privada às ações populares e civis públicas.

23 Tornaghi refutava o caráter público da ação penal de iniciativa privada: “Tampouco pode levar à afirmação de que tôda a ação é pública, o fato de serem indisponíveis as formas processuais. Convém não confundir a ação com o processo. De que êste é sempre público não há a menor sombra de dúvida. Também o processo civil é público e ninguém ousará dizer que a ação civil é pública. E, demais, não há na ação privada disposição alguma das formas legais do processo. O de que o ofendido pode dispõe é o direito de agir. Mas se age, tem de fazê-lo na conformidade da lei processual, cujas normas, quando imperativas, 1. s., isto é, quando ordenam ou proíbem um comportamento, não podem ser mudadas pela vontade privada. Afirmar que a ação é pública pelo que fim a que visa é o mesmo que dizer que um brasileiro que se destina à Europa é europeu." (TORNAGHI, Helio. Instituições de processo penal. Rio de Janeiro: Forense, 1959. Vol. III. p. 335).

24 "Por tudo isso, a rigor, constitui uma impropriedade falar em ação penal pública e privada, eis que toda a ação penal é pública, posto que é uma declaração petitória, que provoca a atuação jurisdicional para instrumentalizar o Direito Penal e permitir a atuação da função punitiva estatal. Seu conteúdo é sempre de interesse geral." (LOPES JR., Aury. Direito processual penal. 11. Ed. São Paulo: Saraiva, 2014. p. 359).

25 MARQUES, José Frederico. Elementos de direito processual penal. Vol. I. Campinas: Bookseller, 1998. p. 307.

26 "Além disto, o poder de arquivar a informatio delicti, o Ministério Público o não tem de maneira absoluta. Apesar de dominus a ação penal, ele precisa re- 
doutrinárias denominadas ação penal concorrente ${ }^{27} \mathrm{e}$ ação penal pública subsidiária da pública são exemplos marcantes destinados a evitar o arbítrio potencialmente praticado pelo Ministério Público, especialmente quando não exerce a pretensão acusatória diante de indícios para tal.

A ação penal de iniciativa privada ${ }^{28}$, alvo hoje de críticas $^{29}$, tem origem preponderantemente política, já que o Estado transfere ao particular a legitimidade extraordinária, em verdadeira substituição processual - particular atua em nome próprio na defesa de direito alheio - por considerar que as consequências da instauração da ação penal são tão ou até mais gravosas do que o próprio resultado do ato delituoso ${ }^{30}$.

Dentre as suas subdivisões, interessa-nos para os fins da reflexão proposta, a ação penal de iniciativa privada subsidiária da pública, prevista nos arts. $5^{\circ}$, LIX da Constituição da República, 29 do Código de Processo Penal e 100, $\$ 3^{\circ}$ do Código Penal, criadores de um controle externo da atividade acusatória desempenhada pelo Ministério Público.

querer o arquivamento ao juiz (Código de Processo Penal, artigo 28), o que se dá justamente em consequência do princípio da legalidade. O órgão judiciário é chamado a intervir, na qualidade de fiscal do princípio da obrigatoriedade da ação penal.” (MARQUES, José Frederico. Elementos de direito processual penal. Campinas: Bookseller, 1998. Vol. I. p. 311).

27 Súmula n. 714 do STF: "É concorrente a legitimidade do ofendido, mediante queixa, e do Ministério Público, condicionada à representação do ofendido, para a ação penal por crime contra a honra de servidor público em razão do exercício de suas funções".

O projeto do novo Código de Processo Penal termina a existência da ação penal privada propriamente dita e personalíssima, preservando apenas a subsidiária da pública, por força do mandamento constitucional.

29 "O interesse que move o Ministério Público não se liga à pessoa do ofendido, mas é um interesse não personificado: difuso. Em uma ordem jurídica que se deseja democrática não há espaço para um processo penal derivado de interesses individuais, ainda que relevantes, pois o crime atinge valores coletivos reinantes na sociedade como um todo." (JARDIM, Afrânio Silva; AMORIM, Pierre Souto Maior Coutinho de. Direito processual penal: estudos e pareceres. 14. Ed. Salvador: Juspodivm, 2016. p. 467).

30 "Na ação penal privada (é o que explica BATTAGLINI, no tocante ao diritto di querela), há 'uma subordinação do interesse público ao interesse privado, que decorre ou da conveniência para o Estado em sopesar o interesse privado em face do interesse público, embora bem grande este ou da tenuidade do interesse público, ou, finalmente, dos dois motivos combinados." (MARQUES, José Frederico. Elementos de direito processual penal. Campinas: Bookseller, 1998. Vol. I. p. 324). 
Seu cabimento está relacionado à inércia do Ministério Público em promover a ação penal de iniciativa pública cabível para apuração do fato delituoso. Por inércia, leia-se a postura de desídia, inatividade do órgão ministerial, seja para apuração do fato delituoso mediante investigação direta, pela requisição de diligências após conclusão do inquérito, pelo requerimento de arquivamento do inquérito policial ou pelo decurso do prazo legal para oferecimento da denúncia ${ }^{31}$.

Pelo que se expôs até agora no tocante à ação penal de iniciativa pública incondicionada, condicionada à representação e de iniciativa privada, há a existência de três níveis de interlocução entre a persecução penal e a vontade do sujeito passivo em ver a conduta criminosa apurada, levando em consideração o consentimento, a disponibilidade do direito e o chamado strepitus judicii, a repercussão derivada da instauração da ação penal na esfera de intimidade da vítima.

Quando construiu a disciplina das ações penais o Estado reconheceu três graus de tutela de bens jurídicos penais. O primeiro deles de caráter praticamente indisponível ${ }^{32}$, seria o das ações penais de iniciativa pública incondicionada, em que a apuração do fato criminoso, dada a sua gravidade, supera eventual necessidade de consentimento da vítima e também não se submete a discricionariedade do legitimado para ação. Havendo a presença de justa causa (suporte probatório mínimo) está o acusador legitimado e obrigado a iniciar o processo penal com o oferecimento da ação penal, independentemente da repercussão que possa advir da persecução estatal.

O segundo nível considera equivalentes ${ }^{33}$ a importância da apuração do fato criminoso e a necessidade de se buscar o consentimento

31 JARDIM, Afrânio Silva; AMORIM, Pierre Souto Maior Coutinho de. Direito processual penal: estudos e pareceres. 14. Ed. Salvador: Juspodivm, 2016. p. 475.

32 A Lei dos Juizados Especiais Criminais e a de Organizações Criminosas quando tratam dos institutos despenalizadores (transação penal e suspensão condicional do processo - arts. 76 e 89 da Lei n. 9.099/95) e da possibilidade de não oferecimento da denúncia no caso de colaboração (art. $4^{\circ}, \S 4^{\circ}$ da Lei n. 12.850/2013) flexibilizam a obrigatoriedade e indisponibilidade da ação penal.

33 "Em certos crimes, a conduta típica atinge tão seriamente o plano íntimo e secreto do sujeito passivo que a norma entende conveniente, não obstante a lesividade, seja considerada a sua vontade de não ver o agente processado, evitando que o bem jurídico sofra outra vez a lesão por meio do strepitus fori. 
do ofendido, seja por meio de representação ou requisição do Ministro da Justiça, em razão da repercussão do crime. A ação penal de iniciativa pública passa a ser condicionada a essa prévia manifestação. No entanto, por conservar a legitimidade nas mãos do Estado (Ministério Público), a obrigatoriedade e a indisponibilidade da pretensão subsistem.

No último nível fica estabelecido que a apuração do fato criminoso é menos importante que o consentimento da vítima, visto que a repercussão decorrente da persecução penal é tamanha, a ponto de causar maiores males ao ofendido ${ }^{34}$. Por essa razão, o legislador cede ao particular a avaliação quanto a deflagração da ação penal de iniciativa privada (consentimento) e a própria disponibilidade e conveniência de seu prosseguimento (perdão, renúncia e desistência).

Saindo do terreno da ação penal de iniciativa privada subsidiária, é importante considerar outra modalidade de controle externo do exercício da pretensão penal, decorrente do regramento do art. 28 do Código de Processo Penal. O dispositivo atribui ao juiz aptidão para deferir a promoção de arquivamento do inquérito policial ou, em caso de discordância dos termos ali postos pelo membro do órgão ministerial, submeter à apreciação do Procurador Geral de Justiça (Ministério Público Estadual) ou às Câmaras de Coordenação e Revisão (Ministério Público Federal) a proposta de arquivamento ${ }^{35}$. Nessa ótica, haveria o exercício de um controle externo (juiz) somado ao controle interno (chefia institucional).

Há uma colisão de interesses, entre a exigência da repressão do sujeito ativo e a vontade da vítima, de que a sociedade não tome conhecimento do fato que lesionou a sua esfera íntima. Nestes casos, em consideração ao segundo interesse, o Estado permite que a conveniência do exercício da ação penal seja julgada pela vítima ou eu representante legal.” (JESUS, Damásio E. Direito Penal. 28. Ed. São Paulo: Saraiva, 2005. Vol. I. p. 658).

34 "Nessas hipóteses, a lei, atendendo à tenuidade da lesão, atendendo ao seu caráter tão profundamente particular, cujo strepitus judicii, afetando a honra das pessoas e a dignidade das famílias, pode causar maior mal que a impunidade do próprio crime à sociedade, e atendendo, ainda, que, nesses casos, a produção da prova depende quase exclusivamente do concurso do ofendido, o Estado, então, concede ao particular ou a seu representante legal o jus persequendi in judicio." (TOURINHO FILHO, Fernando da Costa. Processo Penal. 29. Ed. São Paulo: Saraiva, 2007. p. 25).

35 "Como se vê, no procedimento de arquivamento, o juiz funciona como fiscal do princípio da obrigatoriedade, exercendo função anômala, porque não jurisdicional. Destarte, a decisão de arquivamento jamais terá a eficácia de uma 
É verdade que o art. 28 do CPP não trata de previsão do exercício subsidiário da ação penal, como ocorre na ação penal privada, por buscar a atividade do juiz a preservação do princípio da obrigatoriedade da ação penal. A remessa dos autos à chefia do Ministério Público objetiva assegurar que o órgão ministerial possa rever a questão do arquivamento e se manifestar terminativamente a seu respeito.

Não podemos deixar de considerar a existência de um controle interno do exercício da pretensão penal acusatória. Modernamente, fala-se em uma ação penal de iniciativa pública subsidiária da pública, apontando-se três hipóteses diversas. Trata-se de uma classificação com maior repercussão na dimensão paralela dos concursos públicos para carreiras jurídicas $^{36}$ do que nos próprios livros de doutrina ${ }^{37}$.

Em linha de síntese, o primeiro exemplo desta modalidade de ação penal estaria previsto no Decreto-Lei no 201/1967, que regulamenta o processo e julgamento dos prefeitos pela prática dos crimes de responsabilidade. Adota-se um rito semelhante ao dos crimes praticados por funcionário público regulado pelo Código de Processo Penal, pois antes de oferecida a denúncia há a necessidade de defesa prévia. Conforme a dicção do referido Decreto-Lei, os órgãos federais, estaduais ou municipais, interessados na apuração da responsabilidade do prefeito, podem requerer a abertura do inquérito policial ou a instauração da ação penal pelo Ministério Público, bem como intervir, em qualquer fase do processo, como assistente da acusação (art. $2^{\circ}, \S 1^{\circ}$ ).

A legitimidade para a deflagração da ação penal nestes crimes, como regra geral, pertence ao Ministério Público estadual. Entretanto, diante de eventual inércia daquele órgão acusatório, a ação penal poderá ser deflagrada pelo Procurador-Geral da República, nos termos do

sentença de mérito. “ (JARDIM, Afrânio Silva; AMORIM, Pierre Souto Maior Coutinho de. Direito processual penal: estudos e pareceres. 14. Ed. Salvador: Juspodivm, 2016. p. 205).

36 "Há ainda quem admita uma terceira classificação da ação pública: a ação penal pública subsidiária da pública. Para os adeptos dessa orientação, a referida modalidade de ação penal encontra-se prevista em duas situações" (AVENA, Norberto. Processo penal esquematizado. 4. Ed. São Paulo: Método. 2012. p. 225).

37 TOURINHO FILHO, Fernando da Costa. Processo Penal. 29. Ed. São Paulo: Saraiva, 2007. p. 508. 
art. $2^{\circ}, \S 2^{\circ}$, do epigrafado Decreto-Lei. Seria um caso de legitimação supletiva do chefe do Ministério Público da União, evitando eventual impunidade advinda da desídia do parquet estadual.

A segunda hipótese sugerida por esta classificação seria a do art. 27 da Lei n ${ }^{\circ}$ 7.492/1986, referente à atribuição para oferecimento da denúncia diante da omissão do Procurador da República em deflagrar a ação penal em crimes praticados contra o sistema financeiro. $\mathrm{O}$ dispositivo legal permite ao ofendido representar ao Procurador-Geral da República, que poderá oferecer a denúncia ou designar outro membro do MP para assim o fazer.

Por último, aponta-se o art. $357, \S \S 3^{\circ}$ e $4^{\circ}$, do Código Eleitoral como outra hipótese de ação penal de iniciativa pública subsidiária da pública. Na inércia do órgão do MP eleitoral em oferecer a denúncia, pode o juiz oficiar ao Procurador Regional para que outro membro seja designado.

Se pensarmos sob a ótica do princípio da unidade do Ministério Público, chegaríamos a conclusão que todos os exemplos antes indicados na ação penal de iniciativa pública subsidiária da pública referirse-iam muito mais a matéria de atribuição e seu eventual deslocamento do que a uma verdadeira legitimação subsidiária ${ }^{38}$, razão pela qual a classificação como modalidade autônoma de ação penal seria inadequada.

Nossa opinião assim se escora na perspectiva moderna da unidade, que compreende o caráter uno, no plano funcional-finalístico, dos diversos Ministérios Públicos. É dizer, a opção do constituinte e do legislador ordinário é considerar que o Ministério Público quando encarado do ponto de vista do exercício de atividade-fim constitui uma única instituição, pouco importando o seu fracionamento federativo, raciocínio este também aplicável à Defensoria Pública.

38 "A dispor sobre a existência de um único Ministério Público, que abrangeria uma diversidade de instituições autônomas entre si, a Constituição de 1988 encampou 'a unidade com inclusão da variedade'. A partir dessa conclusão pode-se afirmar que o princípio da unidade, contemplado no $\S 1^{\circ}$ do art. 127 da Constituição de 1988 atua como evidente reforço argumentativo, indicando que tanto o Ministério Público da União como os Ministérios Públicos dos Estados, cada qual em sua esfera de atribuições, atuam como partes indissociáveis de um único e mesmo corpo.” (GARCIA, Emerson. Ministério público: organização, atribuições e regime jurídico. 4. Ed. São Paulo: Saraiva, 2014. p. 123). 
Pois bem! Compreendidos os espaços de iniciativa da ação penal e os níveis de tutela de bens jurídicos penais, torna-se necessário adentrar ao campo do direito material propriamente dito para melhor compreensão da titularidade destes bens.

\section{II - A DEFESA DE BENS JURÍDICOS PELAS PESSOAS JURÍDICAS DE DIREITO PÚBLICO INTERNO NOS CHAMADOS "CRIMES VAGOS"}

A moderna doutrina penal há muito rediscute o conceito de bem jurídico questionando até que ponto essa categoria seria útil e adequada diante da morfologia conceitual aplicada a partir de visões positivistas, funcionalistas, neokantianas e ontológicas. Muitos doutrinadores sempre trataram o bem jurídico como um critério criminalizador, negando o seu caráter de objeto do Direito Penal, enquanto outra parcela sempre enxergou o bem jurídico como o próprio alvo da proteção jurídica ${ }^{39}$.

39 "Então, embora possa haver, nos dias atuais, correntes que neguem importância ao bem jurídico, pretendendo a consideração do Direito Penal exclusivamente em seu sentido sistêmico, como a defendida por Günther Jakobs, na Universidade de Bonn - Alemanha, não parece correto abandonar a referência ao bem jurídico e, portanto, aos valores e interesses fundamentais da sociedade, mesmo que possam agora também assumir caráter supra-individual, pois são esses valores que deverão constituir os mínimos éticos cuja expectativa social é tutelada pelas normas que compõem o sistema penal. Porém, se não se pode, de um lado, como a maior parte da doutrina, concordar com uma concepção exclusivamente sistêmica do direito penal, em seu sentido autopoiético - no qual os indivíduos não fazem parte do sistema social, e sim de seu entorno, na expressão de Luhmann -, é inegável, de outro, que o sentido comunicacional da sociedade ganha importância fundamental no exame da legitimidade da intervenção penal. Se é assim, a concepção pessoal do bem jurídico não se revela mais adequada, nesse novo contexto, estando a merecer estudo mais aprofundado, para o fim de revisão. A compreensão do real sentido do bem jurídico-penal, no contexto de um sistema aberto, baseado em uma sociedade pluralista na qual os valores se pautam no mundo de vida de cada um, deve levar em conta os partícipes da comunicação, que se movem no horizonte de possibilidades irrestritas de entendimento a fim de atingir a auto-realização social. Dentro desse sistema, o bem jurídico ganhará contornos mais públicos, mas ainda continua a representar o padrão crítico irrenunciável pelo qual se deve aferir a observância à função e, consequentemente, a legitimação do direito penal em cada caso concreto." (BECHARA, Ana Elisa Liberatore S. O rendimento da teoria do bem jurídico no direito penal atual. Revista Liberdades. São Paulo: IBCCRIM. N. 01, mai-ago, 2009. p. 27). 
Como bem adverte Juarez Tavares, a conceituação do bem jurídico assumirá sua respectiva forma a partir do modelo punitivo adotado pelo ordenamento jurídico. A perspectiva positivista e neokantiana ${ }^{40}$, por exemplo, traz a concepção de bem jurídico a partir da norma definidora de interesses juridicamente protegidos. No entanto, refutando a origem positivista o autor também pondera "que a noção de bem jurídico não pode ser posta como legitimação da incriminação, mas como sua delimitação...” ${ }^{41}$.

De fato, talvez não seja mais atual a visão do Direito Penal como protetor do bem jurídico. No entanto, é inegável que nosso sistema ainda é conformado para expressar a proteção dos direitos da pessoa humana e de outros direitos que permitam o pleno exercício da existência humana ${ }^{42}$, como é o exemplo da preservação de um meio ambiente sadio e sustentável ${ }^{43}$. Ainda que a tese funcionalista de Jakobs refute a necessidade de ligação entre intervenção penal e bem jurídico, como também aponta Cirino do Santos ${ }^{44}$, fato é que nossa cultura ainda se escora nessa realidade.

40 "Dadas as variedades com que se apresenta, é praticamente impossível conceituar exaustivamente bem jurídico. As conceituações, geralmente, procuram esclarecer de forma sintética as diretrizes do pensamento jurídico quanto ao conteúdo do injusto e às finalidades da norma, o que conduz a confundi-los, indevidamente com o próprio bem jurídico.” (TAVARES, Juarez. Teoria do injusto penal. 3. Ed. Belo Horizonte: Del Rey. 2003. p. 181).

41 TAVARES, Juarez. Teoria do injusto penal. 3. Ed. Belo Horizonte: Del Rey. 2003. p. 201.

42 "Em suma, a tese do bem jurídico como critério de criminalização e como objeto de proteção penal - ainda que a concreta lesão do bem jurídico indique a ineficácia da proteção - explica o Direito Penal como garantia jurídico-política das formações sociais capitalistas.” (SANTOS, Juarez Cirino dos. Direito penal: parte geral. 2. Ed. Rio de Janeiro: Lumen Juris, 2007. p. 16).

43 "Desse modo, a proteção de direitos humanos, como condição de defesa individual perante o Estado despótico, além de ser um programa, é fundamento do próprio Estado democrático, que se deve, pois, ocupar de garantir a todos o pleno exercício de seus direitos fundamentais. Isso quer dizer que a legitimidade da atuação estatal, no sentido de um exercício protetivo, está vinculada a que sua atuação se faça necessária para impedir a interferência e outrem no exercício de direitos do próprio indivíduo, o que fundamenta a constituição de um direito subjetivo desse indivíduo a determinada condição de garantia." (TAVARES, Juarez. Teoria do injusto penal. 3. Ed. Belo Horizonte: Del Rey. 2003. p. 181).

44 SANTOS, Juarez Cirino dos. Op. cit. p. 16. 
Enquanto o Direito Penal se "ocupar” da proteção de bens jurídicos, espaço ainda haverá para debater a quem eles se destinam. E, dentre os pressupostos clássicos da teoria do crime, sabemos que as infrações penais podem ter vários sujeitos passivos, sempre a depender do bem jurídico tutelado pelo tipo penal infligido.

A regra geral é a de que a defesa de todos os bens jurídicos pertence ao Estado. Isto o torna um sujeito passivo constante, universal, ou seja, em todas as infrações penais, o Estado é vítima, seja pelo ataque direto ao seu interesse (crimes contra a administração pública), seja pela simples inobservância de suas normas, em virtude do conceito formal de crime (crimes contra vida, por exemplo).

Há, no entanto, categorias de infrações penais que contemplam uma duplicidade ou multiplicidade de sujeitos passivos, por considerar tanto o Estado e pessoas naturais ou jurídicas como titulares do direito violado (crimes contra a honra, crimes contra a dignidade sexual, dentre outros), em virtude do desdobramento do conceito material de crime.

Poderíamos assim compreender na infração penal em que haja multiplicidade de sujeitos passivos, o Estado na condição de sujeito indireto (violação à norma jurídica) e a vítima ostentando a qualidade de sujeito passivo direto por sofrer a agressão ao bem jurídico.

É para esta última categoria específica de crimes que o art. $5^{\circ}$, LIX da CRFB dirige a chamada ação penal de iniciativa privada subsidiária pública, evitando que haja impunidade do delito em razão da inércia do órgão acusador. Sempre que o Estado resta inerte na persecução penal, emerge ao sujeito passivo direto da conduta a legitimidade para agir e ver apurada a infração - ação penal de iniciativa privada subsidiária, desde que aja no prazo decadencial de 6 (seis) meses.

Todavia, a ação penal de iniciativa privada subsidiária foi construída a partir da legitimação de um ofendido determinado, o que afastaria a sua aplicabilidade da coletividade e de entes despersonalizados. Temos, nesses casos, uma situação em que o sistema processual não contempla um instituto capaz de permitir a adequada persecução das condutas delituosas em que a proteção do bem jurídico espelha a coletividade.

Resta-nos então, identificar se haveria espaço para o exercício de outra modalidade de legitimação para ação penal, específica para a tutela de bens jurídicos referentes à coletividade, sempre que houver 
inércia do órgão do Ministério Público. Para tanto, torna-se necessário delimitar a extensão desta proteção coletiva e indicar quem seriam o(s) protagonista(s) desta proteção jurídica.

Há algum tempo que se discute a existência de bens jurídicos coletivos e difusos penais, especialmente quando levada em consideração a defesa dos direitos humanos, do meio ambiente, da saúde púbica, da segurança viária, da incolumidade e paz pública, dentre outros.

O tipo penal nestes casos tem o propósito de evitar que condutas delituosas possam operar efeitos prejudiciais à sociedade assim considerada, sem que haja uma pessoa diretamente atingida pelo fato criminoso.

Haveria sentido em se admitir que a proteção de bens jurídicos com repercussão particular fosse ainda mais intensa do que a proteção destinada à coletividade? Se respondermos afirmativamente, a extensão da ação penal de iniciativa privada subsidiária seria suficientemente adequada, tornando-se inócua qualquer discussão a respeito de sua extensão.

Entretanto, quando consideramos que a proteção de bens jurídicos deve ser adequada e eficaz a ponto de preservar o convívio sadio entre os integrantes da população, não resta dúvida de que a inércia do Ministério Público na promoção da apuração do fato criminoso transindividual não deve passar incólume.

O caráter transcendente dos crimes cujo sujeito passivo é a coletividade demanda que haja uma alternativa a desídia do Ministério Público na sua tutela, permitindo-se que outros personagens possam defender os interesses da sociedade, em caráter excepcional.

A concentração de poderes é uma premissa já rechaçada na defesa de direitos coletivos não penais, como veremos mais adiante. No campo penal, pensamos que essa premissa também seja discutida, sem que isso signifique uma perda de poderes do Ministério Público, já que ele deve ser o tutor dos interesses penais.

É por esta razão que este estudo propõe uma reinterpretação do papel da Defensoria Pública e da Fazenda Pública na defesa da coletividade, especialmente para atuação supletiva nos casos de desídia do órgão acusatório na tutela de direitos difusos e coletivos de natureza penal ${ }^{45}$.

45 O Código de Defesa do Consumidor (Lei n. 8.078/90) é o diploma normativo que melhor define a distinção entre direitos difusos e coletivos, 


\section{III - O PAPEL DE PROTEÇ̃̃O DE DIREITOS TRANSINDIVIDUAIS CONFERIDO À DEFENSORIA PÚBLICA E ÀS PESSOAS JURÍDICAS DE DIREITO PÚBLICO}

É inegável que mesmo antes da reforma operada pela Lei Complementar n. 132/2009, a Defensoria Pública já atuava perante o sistema interamericano de direitos humanos, buscando a defesa das normas do Pacto de San José da Costa Rica e dos demais tratados internacionais pertinentes às suas funções institucionais.

Contudo, foi a Emenda Constitucional n. 80/14 que trouxe marco normativo significativo à instituição, pela constitucionalização da sua função de promoção de direitos humanos. Talvez do ponto de vista prático, a ampliação do texto constitucional não tenha trazido nenhum impacto ao exercício das funções institucionais. No entanto, a amplitude do significado das normas que tratam da Defensoria Pública é que fortalecem a sua intervenção em novos espaços de atuação.

A tese do controle jurisdicional de convencionalidade das leis, muito bem construída por Valerio Mazzuoli ${ }^{46}$ é um dos mais atuais instrumentos de aplicação da Defensoria Pública, na interpretação e combate da práxis jurídico-nacional.

Nesta seara de ideias, a promoção de direitos humanos não pode se resumir a simples invocação das normas da Convenção

verbis: “Art. 81. A defesa dos interesses e direitos dos consumidores e das vítimas poderá ser exercida em juízo individualmente, ou a título coletivo. Parágrafo único. A defesa coletiva será exercida quando se tratar de: I - interesses ou direitos difusos, assim entendidos, para efeitos deste código, os transindividuais, de natureza indivisível, de que sejam titulares pessoas indeterminadas e ligadas por circunstâncias de fato; II - interesses ou direitos coletivos, assim entendidos, para efeitos deste código, os transindividuais, de natureza indivisível de que seja titular grupo, categoria ou classe de pessoas ligadas entre si ou com a parte contrária por uma relação jurídica base; III - interesses ou direitos individuais homogêneos, assim entendidos os decorrentes de origem comum."

46 “...é lícito entender que, para além do clássico "controle de constitucionalidade, deve ainda existir (doravante) um "controle de convencionalidade" das leis, que é a compatibilização das normas de direito interno com os tratados de direitos humanos ratificados pelo governo em vigor no país." (MAZZUOLI, Valerio de Oliveira. O controle jurisdicional da convencionalidade das leis. 3. Ed. São Paulo: RT, 2013. p. 79). 
Americana de Direitos Humanos em Ações Civis Públicas, Habeas Corpus e premiações institucionais.

As medidas de aplicação dos direitos humanos devem ser muito mais profundas diante da missão constitucional conferida à Defensoria Pública, compreendendo a educação em direitos, a promoção, difusão, defesa e conscientização dos direitos humanos, na forma do art. $4^{\circ}$, III da Lei Complementar n. 80/94.

A promoção de direitos humanos significa o papel de defesa das vítimas também enquanto grupo. Essa proteção representa um verdadeiro papel repressivo da Defensoria Pública, buscando a responsabilização de todos aqueles que atentarem contra direitos humanos, especialmente quando praticadas condutas criminosas atentatórias à coletividades, como ocorre no caso do oferecimento de denúncias perante a Comissão Interamericana de Direitos Humanos.

É verdade que a doutrina internacional aponta que a tutela penal tem atropelado direitos humanos, especialmente quando se discute a defesa contra atos terroristas, inclusive com a possibilidade de derrogação das disposições das convenções sobre direito humanos ${ }^{47}$, a exemplo do art. $15^{\circ}$ da Convenção Europeia de Direitos do Homem.

A pretexto de protegê-los, o Direito Penal vem se tornando um verdadeiro instrumento de violação das normas de direitos humanos, especialmente aquelas destinadas à proteção do acusado.

Sobre a potencial deficiência na proteção dos direitos humanos, mérito deve ser destacado à Defensoria Pública, instituição que há mais de uma década tem assegurado a defesa das normas de direitos humanos nas mais variadas vertentes.

Essa, aliás, é uma das razões pelas quais a Organização dos Estados Americanos - OEA, anualmente edita atos reforçando a importância de se preservar a autonomia da Defensoria Pública, por reconhecer a importância da instituição dentro de um estado nacional e, principalmente, para a tutela dos direitos humanos.

47 CASSEL, Doug. International human rights law and security detention. Disponível em: http://scholarship.law.nd.edu/cgi/viewcontent.cgi?article=1681\&context=law_faculty_scholarship. Acesso em: 29 set 2016 . 
O caráter universal dos direitos humanos os transformam em verdadeiros direitos difusos da humanidade, exigindo da instituição um perfil muito mais combativo e inclusivo, utilizando-se de medidas não só judiciais (ações individuais e coletivas), mas também extrajudiciais (termos de ajustamento de conduta, recomendações administrativas, audiências públicas e atendimento in loco), tanto no âmbito interno como em sede internacional.

O fato de a Defensoria Pública exercer a defesa dos direitos humanos da população carcerária e dos acusados no processo penal não a impedirá de tutelar, supletivamente outros direitos humanos relacionados às vítimas de crimes, tal como já ocorre, por exemplo, no caso das mulheres vítimas de violência doméstica.

Nesta mesma perspectiva de direitos difusos, não podemos nos olvidar do papel atribuído à Defensoria Pública para o desempenho da tutela coletiva. O processo histórico-evolutivo de sua participação nesta forma de tutela de interesses revela o quão bem intencionada é a instituição no plano da defesa dos direitos difusos, coletivos e individuais homogêneos, facilitando o acesso à justiça dos grupos mais vulneráveis ${ }^{48}$.

O primeiro passo da Defensoria Pública no plano das ações coletivas se deu através do desempenho da representação processual das associações legitimadas que não poderiam arcar com os custos de um advogado e procuravam a instituição para o ajuizamento da ação coletiva.

Posteriormente, com o advento do Código de Defesa do Consumidor, reconheceu-se que os órgãos da Defensoria Pública voltados para a assistência jurídica de consumidores poderiam exercer a legitimidade para ação coletiva com suporte no art. 82, III $^{49}$ daquele diploma.

48 "Do ponto de vista funcional e levando-se em consideração a atual realidade da Defensoria Pública, a grande alteração operada pela Emenda Constitucional n. 80/2014, no art. 134, caput, refere-se a atuação coletiva da instituição.” (SILVA, Franklyn Roger Alves. A nova formatação constitucional da defensoria pública à luz da emenda constitucional n. 80/14. Disponível em: <http://www. cursocei.com/reflexos-da-ec-n-80-de-2014>. Acesso em: 13 mai 2016).

49 "O presente trabalho é dedicado à conquista da legitimidade para as ações coletivas. Conquista? Mas a Defensoria Pública já não vinha atuando com desembaraço nesse terreno? E já não havia julgados de vários tribunais brasileiros, inclusive do Superior Tribunal de Justiça, afirmando a legitimidade da instituição para demandas coletivas? De fato, a Defensoria 
O sucesso da atuação da Defensoria Pública no plano consumerista levou o legislador a conceder a ampla legitimação, através da inclusão da instituição no rol do art. $5^{\circ}$ da Lei n. $7.347 / 85$ por meio de alteração operada pela Lei n. 11.448/07.

O próprio Superior Tribunal de Justiça em acórdão paradigmático que tratava da legitimidade institucional com fundamento na atuação em defesa de consumidores ${ }^{50}$, reafirmou na ratio decidendi que a legitimação da Defensoria Pública prevista na Lei n. 7.347/85 derivava da máxima interpretação das normas constitucionais, em especial os arts. $5^{\circ}$, LXXIV e 134, que reconheciam o direito a assistência jurídica integral e gratuita.

Houve, no entanto, o ajuizamento da Ação Direta de Inconstitucionalidade n. 3.943, perante o Supremo Tribunal Federal. Nesta ação pretendia-se a declaração de inconstitucionalidade do art. $5^{\circ}$, II da Lei da Ação Civil Pública, sob o fundamento de que a tutela coletiva desvirtuaria o desempenho das funções institucionais da Defensoria Pública.

Não obstante o questionamento da constitucionalidade da legitimação da Defensoria Pública, a instituição foi adiante no plano da tutela coletiva e, na reforma da Lei Complementar n. 80/94, realizada em 2009 com o advento da Lei Complementar n. 132, introduziu diversas novas funções no seu rol de atuação (art. $4^{\circ}$ ), dentre elas o reforço da legitimidade para a tutela coletiva.

A principal mudança de paradigmas normativos ocorreu no ano de 2014, com o advento da Emenda Constitucional n. 80 que alçou ao nível da Constituição da República a legitimidade coletiva da Defensoria Pública. Esta pequena reforma no texto de nossa Carta teve grande relevância para a instituição, especialmente no julgamento da

Pública vem frequentando assiduamente o processo coletivo, até porque estamos no século XXI e os conflitos apresentam-se cada vez mais complexos e abrangentes." (SOUSA, José Augusto Garcia de. A nova lei 11.448/07, os escopos extrajurídicos do processo e a velha legitimidade da defensoria pública para ações coletivas. In: SOUSA, José Augusto Garcia de. A defensoria pública e os processos coletivos. Rio de Janeiro: Lumen Juris, 2008. p. 189-190).

50 STJ - Recurso Especial No 912.849-RS (206/0279457-). Min. José Delgado. 
ação de inconstitucionalidade. Um dos fatores levados em consideração pelo Supremo Tribunal Federal ao reconhecer a constitucionalidade da legitimação da Defensoria Pública para o ajuizamento de ações coletivas era exatamente a existência de previsão constitucional da legitimidade.

Se partirmos da premissa de que a Defensoria Pública dispõe de atribuição plena para a defesa dos direitos humanos e de interesses difusos e coletivos, inclusive com amparo na jurisprudência do Supremo Tribunal Federal, nos resta agora identificar a extensão desta missão no processo penal.

Em momento anterior deste tópico indicamos a pertinência do Código de Defesa do Consumidor para a definição dos direitos difusos, coletivos e individuais homogêneos ${ }^{51}$. Foi nele, inclusive, que apontamos o embrião de legitimidade extraordinária da Defensoria Pública para a tutela coletiva. Agora, mais uma vez, invocaremos o conteúdo de nosso código consumerista, desta vez para afirmar um primeiro pilar de sustentação da legitimidade da Defensoria Pública para a deflagração de uma ação penal supletiva.

De acordo com o seu art. 80, no processo penal relativo aos crimes ou contravenções previstos pelo CDC ou em outros diplomas de proteção consumerista, podem intervir como assistentes do Ministério Público, os legitimados indicados no art. 82, inciso III e IV (entidades e órgãos da Administração Pública, direta ou indireta, ainda que sem personalidade jurídica, especificamente destinados à defesa dos interesses e direitos protegidos pelo CDC e as associações legalmente constituídas há pelo menos um ano e que incluam entre seus fins institucionais a defesa dos interesses e direitos de consumidores) e propor ação penal subsidiária, se a denúncia não for oferecida no prazo legal.

O Superior Tribunal de Justiça já considerou que a expressão “entidades e órgãos da Administração Pública” alcança os órgãos de atuação da Defensoria Pública. Assim, tanto ela - instituição públi-

51 "Este dispositivo, com o passar do tempo, veio a se tornar a porta de entrada para a atuação da Defensoria Pública na defesa coletiva. Porém, tal permissivo, por si só, não a autorizava a ingressar com ações civis públicas. De fato, é certo que a Defensoria Pública já era órgão da Administração Pública direta quando houve a promulgação do Código de Defesa do Consumidor." (LIMA, Frederico Rodrigues Viana de. Defensoria pública. Salvador: Juspodivm, 2015. p. 235). 
ca - como os demais órgãos da administração pública podem se habilitar como assistentes de acusação ${ }^{52}$ em causas criminais que versem sobre infrações aos bens jurídicos tutelados pelo Código de Defesa do Consumidor, assim como deflagrarem a ação penal no caso de inércia do Ministério Público.

Inobservado o prazo legal de oferecimento da denúncia, a Defensoria Pública ofereceria a peça acusatória deflagradora da ação penal supletiva ${ }^{53}$, permitindo-se ao Ministério Público aditá-la, repudiá-la ou oferecer denúncia substitutiva, intervir em todos os termos do processo, fornecer elementos de prova, interpor recurso e, a todo tempo, no caso de negligência do autor originário, retomar a ação como parte principal, mediante aplicação da disciplina do art. 29 do CPP.

Este primeiro exemplo, expresso no texto do Código de Defesa do Consumidor é deverás avançado, mas incompleto, já que a não alcança os interesses não relacionados às relações de consumo. Como fica então a legitimidade para defesa de outros direitos difusos e coletivos penais negligenciados pelo Ministério Público?

Pensamos que, da mesma forma prevista pelo CDC, quando houver um direito difuso ou coletivo de índole penal violado por meio de conduta criminosa (crime vago) em que não haja adequada ação ministerial, poderia a Defensoria Pública deflagrar a ação penal, aplicando-se a ela toda a disciplina do art. 29 do CPP (ação penal de iniciativa privada subsidiária da pública).

A vida em coletividade exige a adequada proteção dos direitos e valores mais básicos. Os segmentos sociais vulneráveis merecem ampla proteção, sendo a Defensoria Pública legalmente encarregada de prestar assistência jurídica e defender esses interesses ${ }^{54}$.

52 O dispositivo é uma exceção à clássica exigência de legitimidade e interesse do assistente de acusação no processo penal.

53 Entendemos, neste caso, que a Defensoria Pública deve oferecer uma denúncia, por se tratar do exercício de uma ação penal pública.

54 "Segundo estabelece o art. 4 , XVIII, da LC n. 80/1994, constitui função institucional da Defensoria Pública 'atuar na preservação e reparação dos direitos de pessoas vítimas de tortura, abusos sexuais, discriminação ou qualquer outra forma de opressão ou violência, propiciando o acompanhamento e o atendimento interdisciplinar das vítimas'. A intenção primordial do dispositivo é garantir o amparo jurídico das vítimas, visando preservar as liberdades públicas e demo- 
Que não se diga que a Defensoria Pública não possui papel para a tutela de interesses penais. O legislador construiu a Defensoria Pública como instituição dialética ${ }^{55}$, capaz de assegurar a assistência jurídica e a defesa de interesses nas mais variadas acepções ${ }^{56}$.

Plenamente razoável admitir que a Defensoria Pública possa exercer a pretensão acusatória subsidiária sem desnaturar o seu papel de defesa. Para isso a instituição é organizada a partir de princípios como defensor natural e independência funcional, todos expressos no texto da LC n. 80/94 ${ }^{57}$. Seus Defensores Públicos jamais podem exercer

cráticas, controlar e afastar os atos de barbárie e possibilitar a identificação dos torturadores." (ESTEVES, Diogo; SILVA, Franklyn Roger Alves. Princípios institucionais da defensoria pública. Rio de Janeiro: Forense, 2014. p. 367).

55 O caráter dialético não pode ser confundido com uma suposta esquizofrenia institucional: "Isso, em hipótese alguma, pode significar uma limitação de atuação no campo de defesa, que deve ser amplo. Mas efetivamente no reconhecimento de que esta defesa deve ser ética e feita dentro dos parâmetros institucionais previstos na Constituição. Ou seja, o Defensor não pode ter a esquizofrênica posição de promover os direitos humanos e, ao mesmo tempo, sustentar teses que sustentem tais violações de direitos." (COSTA, Renata Tavares da. Os direitos humanos como limite ético na defesa dos acusados de feminicídio no tribunal do júri. Livro de Teses e Práticas Exitosas. ANADEP: Paraná, 2015. p. 207).

56 "Interessa notar que, na área criminal, tem o defensor público usualmente a atribuição de defesa, e é rara sua atuação como acusador. No entanto, tal mister deve ser exercido sem reservas, eis que direito do usuário. É comum, aqui, discussão sobre a colidência de interesses entre defensores, que impediria a Defensoria de atuar nos dois polos da ação, se o querelado também for carente. A objeção não nos parece procedente." (JUNQUEIRA, Gustavo; ZVEIBEL, Daniel G; REIS, Gustavo Augusto Soares. Comentários à lei da defensoria pública. São Paulo: Saraiva, 2014. p. 80).

57 "Inicialmente, convém esclarecer que não está escrito em lugar nenhum que a Defensoria Pública somente pode atuar em favor dos acusados ou de quem ocupa o polo passivo da ação penal. Muito pelo contrário, alias. A LONDP prevê pelo menos três funções institucionais da Defensoria que se identificam com a proteção da vítima: (I) 'exercer a defesa dos interesses individuais e coletivos da criança e do adolescente, do idoso, da pessoa portadora de necessidades especiais, da mulher vítima de violência doméstica e familiar e de outros grupos sociais vulneráveis que mereçam proteção especial do Estado' (art. $4^{\circ}, \mathrm{XI}$ ); (II) 'patrocinar ação penal privada e a subsidiária da pública' (art. $4^{\circ}, \mathrm{XV}$ ); e (III) 'atuar na preservação e reparação dos direitos de pessoas vítimas de tortura, abusos sexuais, discriminação ou qualquer outra forma de opressão ou violência, propiciando o acompanhamento e o atendimento interdisciplinar das vítimas' (art. $4^{\circ}$, XVIII)." (PAIVA, Caio. Prática penal para defensoria pública. Rio de Janeiro: Forense, 2016. p. 356). 
interesses antagônicos na mesma causa, tal como se observa da norma obstativa de atuação prevista no art. $4^{\circ}$-A, V da LC n. 80/9458.

Não só como representante do querelante na queixa-crime ou representante da vítima habilitada como assistente de acusação $0^{59}$ é que consiste a atuação acusatória da Defensoria Pública. O ordenamento jurídico permite que a instituição possa buscar a tutela penal supletiva em outros momentos.

Se o fundamento da nossa Carta é a dignidade da pessoa humana (art. $1^{\circ}$, III) e a República tem como objetivos a construção de uma sociedade livre, justa e solidária e o de promoção do bem de todos, sem preconceitos de origem, raça, sexo, cor, idade e quaisquer outras formas de discriminação, não nos parece que a atuação supletiva da Defensoria Pública esteja em desalinho com o texto constitucional.

A unidade da Defensoria Pública, sua autonomia funcional e a independência de seus membros permite que a instituição possa zelar supletivamente pela tutela penal nos crimes contra a coletividade, quando negligenciados pelo Ministério Público, sem que isso prejudique o papel de defesa que ela também exerce no processo penal.

Note-se que o papel de defesa desempenhado pela Defensoria Pública consiste em assegurar o acusado o acesso a todas as garantias processuais, permitindo que ele possa exercer o seu direito de defesa em paridade de armas ao órgão acusador.

58 "Assim, enquanto o advogado particular se encontra jungido aos regramentos contidos no código de ética de sua categoria, podendo ocasionalmente, lidar com experiências que suscitem interesses colidentes entre clientes contratados, tal hipótese não se aplica ao defensor público, já que, havendo representante que atue ao lado da vítima concreta de um crime - com ênfase para vítimas de tortura e outros delitos graves, conforme art. $4^{\circ}$, inc. XVIII, da Lei Complementar 80/94 - impõe-se a designação de outro agente da Defensoria Pública que possa agir em favor do agressor." (MARQUES, Karla Padilha Rebelo. Implicações penais e processuais penais da defensoria pública. In: ANTUNES, Maria João et al. Novos atores da justiça penal. Coimbra: Almedina, 2016. p. 333).

"Como representante jurídico do assistente de acusação, a Defensoria Pública pode ter um papel fundamental na formação do convencimento do juiz, pois além de contribuir na produção da prova condenatória, tem a prerrogativa de se manifestar em vários momentos do processo." (DANTAS JUNIOR, Genival Torres. A tutela da vítima pela defensoria pública na persecução penal. Rio de Janeiro: Lumen Juris, 2016. p. 20). 
A missão constitucional de promoção de direitos humanos e da tutela coletiva (art. 134 da CRFB) somada aos objetivos e fundamento da República Federativa do Brasil, traduzem novo paradigma à tutela jurídica de infrações penais que tenham como sujeito passivo a coletividade.

É difícil compreender esse perfil acusatório da Defensoria Pública, ainda que a doutrina institucional inicie uma mudança no perfil institucional da Defensoria Pública, no que toca à tutela repressiva em prol da coletividade, vide a proposta de legitimação para a Ação de Improbidade Administrativa ${ }^{60}$.

Ao assumir a missão de promoção de direitos humanos e de defesa coletiva de direitos, a Defensoria Pública ergue-se como uma instituição não mais caracterizada pela assistência jurídica individual, mas como um personagem multifacetado do sistema jurídico.

Talvez com a experiência de ocupar os bancos da defesa, a Defensoria Pública possa contribuir para o próprio sistema acusatório, sensibilizando seus órgãos sobre formas de exercício pretensão da penal sem inobservância das garantias fundamentais do processo.

Em última análise, a tese que aqui se propõe restringe-se à atividade acusatória em prol da coletividade, quando omisso o Ministério Público na persecução penal, como um desdobramento do perfil solidarista da instituição ${ }^{61}$.

60 "Assim é que, para subsumir a tutela jurisdicional da moralidade administrativa dentro da previsão constitucional afeta à legitimidade das Defensorias Públicas, é bastante a identificação da moralidade enquanto direito transindividual, sendo absolutamente irrelevante sua subcategorização”. (BOSON, Erick Palácio. A defensoria pública e a tutela jurisdicional da moralidade administrativa. Salvador: Juspodivm, 2016. p. 58).

61 "Com a superação do modelo individualista, as funções da Defensoria pluralizaram-se e cresceram em versatilidade. Ganharam uma complexidade maior. A antiga dicotomia restou acanhada e insuficiente. Hoje, podemos enxergar pelo menos cinco tipos distintos de atribuições: a) atribuições ligadas à carência econômica; b) atribuições nas quais se tem, concomitantemente, a proteção de pessoas carentes e não carentes, como acontece, v.g., em uma ação civil pública relativa a direitos difusos; c) atribuições que beneficiam de forma nominal pessoas não necessariamente carentes, repercutindo porém a favor de pessoas carentes, como, por exemplo, a representação judicial de um casal abastado que visa à adoção de uma criança internada; d) atribuições direcionadas a sujeitos protegidos especialmente pela ordem jurídica, possuidores de outras carências que não a econômica, a exemplo de um portador de deficiên- 
Não pode a relação de consumo ter uma proteção jurídica mais intensa do que outros bens jurídicos ocupantes do mesmo pedestal de proteção estatal. Assim, é imperioso averiguar no ordenamento jurídico se há outra norma de legitimação para ação penal. E não é um trabalho tão difícil, bastando olhar para as normas nacionais que regem a Defensoria Pública.

Quando a Lei Complementar n. 80/94 atribui à Defensoria Pública, como uma de suas funções institucionais previstas no art. $4^{\circ}$, XV, "patrocinar ação penal privada e a subsidiária da pública", estaria o ordenamento jurídico definindo uma nova forma de legitimidade através do referido dispositivo?

A resposta, a nosso ver, é parcialmente negativa. Entendemos que a Lei Complementar n. 80/94 inaugura sim uma legitimação para ação penal, mas não com fundamento no art. $4^{\circ}$, XV. Os verbos promover e patrocinar, quando empregados pelo estatuto da Defensoria Pública refletem atividades processuais diversas.

O verbo "promover" significa a atribuição de legitimidade a um indivíduo, entidade, órgão ou instituição para agir em juízo em nome próprio, seja para a defesa de direito próprio ou alheio. "Patrocinar" refere-se à atividade de representação processual conferida pelo ordenamento jurídico aos membros da Defensoria Pública, advogados públicos ou privados, que agem em juízo na qualidade de representantes das partes constituídas (hipossuficientes, vulneráveis, entes públicos, pessoas naturais ou jurídicas).

cia; e) e atribuições em favor primacialmente de valores relevantes do ordenamento, conforme as hipóteses da defesa do réu sem advogado na área criminal e da curadoria especial na área cível. Com a expansão verificada, as funções da Defensoria Pública passaram realmente a não mais caber na dicotomia típicas/atípicas. A simples leitura do rol acima reforça a necessidade de uma nova classificação, no mínimo uma nova terminologia. O que é realmente típico e o que é atípico no rol? Complicado dizer. Seria típica somente a atuação da letra "a"? Mas as hipóteses das letras "b" e "c" também não envolvem pessoas pobres? E a hipótese da letra "d"? É genuinamente atípica, à luz da hodierna pluralização do fenômeno da carência?" (SOUSA, José Augusto Garcia de. O destino de Gaia e as funções constitucionais da Defensoria Pública: ainda faz sentido - sobretudo após a edição da Lei Complementar 132/2009 - a visão individualista a respeito da instituição? In: Uma nova Defensoria Pública pede passagem. Rio de Janeiro: Lumen Juris, 2011. p. 32). 
O que a Lei Complementar n. 80/94 quer dizer com o seu art. $4^{\circ}, \mathrm{XV}$ é que não obstante ter se atribuído o papel de defesa técnica no processo penal à Defensoria Pública não está ela impedida de representar interesses das vítimas, seja por meio da habilitação como assistente de acusação ou mediante ajuizamento das ações penais privadas, em todas as suas modalidades, como representante do ofendido.

O correto então é extrair a legitimação para a tutela penal a partir da leitura do art. $4^{\circ}$, VII da mesma lei quando permite à Defensoria Pública "promover ação civil pública e todas as espécies de ações capazes de propiciar a adequada tutela dos direitos difusos, coletivos ou individuais homogêneos quando o resultado da demanda puder beneficiar grupo de pessoas hipossuficientes" e do art. $4^{\circ}$, III quando refere-se ao papel de "promover a difusão e a conscientização dos direitos humanos, da cidadania e do ordenamento jurídico”.

A expressão "promover todas as espécies de ações" constante do art. $4^{\circ}$, VII da LC n. 80/94 deve significar o emprego de medidas também na seara penal para a defesa dos direitos difusos e coletivos. Aqui conteria uma autorização, ou melhor, legitimação para a Defensoria Pública agir em juízo ou fora dele para a defesa destes direitos ${ }^{62}$, inclusive na justiça criminal.

A soma do art. 80 do CDC com o art. $4^{\circ}$, incisos III e VII da LC n. 80/94 permite concluir que a Defensoria Pública tem legitimação para atuar nas persecuções penais que versem sobre crimes atentatórios aos interesses difusos e coletivos penais, bem como aos direitos humanos, também em suas vertentes transindividuais ${ }^{63}$.

62 Esta legitimação permitiria à Defensoria Pública valer-se de todos os instrumentos de tutela dos interesses da coletividade, a exemplo da ação civil pública, da ação de improbidade administrativa, do mandado de segurança coletivo, do compromisso de ajustamento de conduta, da recomendação administrativa, dentre outros.

63 “Aqui é importante assinalar que a relação entre Estado e sociedade, quanto à realização dos direitos econômicos, sociais e culturais, não é unívoca, isto é, não há um único interesse público envolvido, mas uma grande contradição entre os interesses dos diversos grupos sociais e destes com os interesses individuais. Daí que não pode ser aceita a asserção de que os direitos humanos sociais constituem uma categoria diversa dos direitos difusos e coletivos, como se fosse uma mera ampliação da dualidade Estado-indivíduo, própria dos direitos civis e políticos, esta sim de outra natureza. Na realidade, a possi- 
Caminhando já para a conclusão deste estudo, é importante apenas o reforço teórico quanto à extensão desta legitimidade, extraída das normas disciplinam o papel da Defensoria Pública. Estes dispositivos contemplariam uma legitimação plena ou supletiva da Defensoria Pública quando o Ministério Público se quedasse inerte na apuração do

bilidade de prestação estatal é múltipla e certamente não tem como alcançar todos os interesses envolvidos, seja pela limitação de ordem material, seja pela contradição eventual entre alguns deles, no que coincide a realização dos direitos sociais com a característica da litigiosidade intensa dos interesses transindividuais. Também a indeterminação dos sujeitos é comum a grande parte dos direitos humanos, com especial destaque para os ditos "globais", também conhecidos como "direitos de solidariedade". Neste caso, os direitos ao meio ambiente saudável, à paz, ao desenvolvimento sustentado, à livre determinação dos povos, entre outros, possuem o dado comum de pertencerem a um conjunto impreciso de pessoas, se não a toda a humanidade, unidas por uma situação de fato e pelo interesse comum de garantir a qualidade de vida no planeta. Ademais, a indivisibilidade do objeto é evidente, pois ainda que seja do interesse de cada membro do grupo, categoria ou classe social a proteção do interesse, a prestação correspondente não pode ser realizada, senão tendo em vista toda a comunidade, sem possibilidade de sua divisão em fração ou quota. Na realidade, os direitos humanos globais são típicos interesses difusos positivados ou direitos difusos. Enquadram-se plenamente nas características gerais comuns a todos os interesses transindividuais, já descritas acima, que constituem uma nova classificação das relações jurídicas, para além do esquema individualista dual, dentro do qual podem caber inúmeros direitos substantivos, desde que as demandas que regulem possuam os mesmos elementos construídos pela doutrina e referendados pela legislação. Igualmente, aqui podem ser vislumbrados os direitos econômicos, sociais e culturais, cujas demandas possuem, ao lado do sentido individual - como condição de exercício dos direitos civis e políticos, no que se afastam dos interesses difusos e coletivos - o de garantir a segmentos vulneráveis prestações que reduzam ou eliminem situações de desigualdade na sociedade. Tais conjuntos de pessoas dificilmente possuem o que o Código de Defesa do Consumidor chama de "relação jurídica base" (art. 81, § único, II), estando vinculadas pelo simples fato de possuírem características comuns. Suas demandas não são individualizáveis e as obrigações estatais decorrentes das normas constitucionais ou dos tratados internacionais são indivisíveis, isto é, não podem, em regra, serem realizadas tendo em vista uma pessoa determinada. Aliás, é a desigualdade material que constitui o dado central identificador do grupo social (que não necessariamente corresponde à realidade de cada um dos seus membros), em razão do que as providências eventualmente adotadas o são em vista da situação do grupo e não do indivíduo, muitas vezes não identificável." (WEISS, Carlos. Os direitos humanos e os interesses transindividuais. Disponível em: <http://www.pge.sp.gov.br/centrodeestudos/bibliotecavirtual/Congresso/xtese3.htm>. Acesso em: 13 jun 2016). 
fato delituoso e não houvesse outros instrumentos de caráter não penal para a tutela de bens jurídicos difusos e coletivos penais atingidos?

Para isso, cremos que o tema deva ser interpretado à luz da Constituição da República. O art. 129, I define como função institucional do Ministério Público "promover, privativamente, a ação penal pública, na forma da lei”. Todos sabemos que a Constituição da República, quando define competências legislativas, emprega significados diversos às expressões "privativa" e "exclusiva”, atribuindo a primeira um caráter restritivo e à segunda um caráter excludente.

Se nos utilizarmos do mesmo raciocínio constitucional, com olhar para o art. 129, quando a Carta se refere à matéria ou ação "exclusiva", apenas o órgão ou entidade indicado poderá exercer a parcela de poder que lhe é conferida. Por outro lado, quando há o emprego do termo "privativo", significa dizer que apenas àquele órgão detém poder, mas impeditivo não há a que o poder possa ser diluído entre outros órgãos por meio de lei ${ }^{64}$.

Sendo a legitimidade do Ministério Público para a ação penal privativa e detendo ele também a missão de defesa da ordem jurídica e dos direitos difusos e coletivos, cremos que a atribuição da Defensoria Pública para o patrocínio de eventual ação penal que verse sobre direito difuso ou coletivo penal deva ocorrer de modo supletivo, em complementação ao art. $5^{\circ}$, LIX da Constituição, que trata da ação penal de iniciativa privada subsidiária da pública.

Do mesmo modo, torna-se adequado compreender que as pessoas jurídicas de direito público interno, conforme a repartição constitucional de competências (arts. 21, 22 e 23 da CRFB) possam também partilhar de uma ação penal supletiva, ocupando seu polo ativo, em atenção ao papel do Estado em zelar pela defesa dos bens jurídicos. O art. 80 do CDC é expresso nesse sentido, quando outorga aos órgãos da administração pública o encargo de defesa das vítimas consumidoras na seara penal.

Se a migração de polos processuais já é uma realidade aplicada à Fazenda Pública, vide arts. $6^{\circ}, \S 3^{\circ}$ da Lei n. 4.737/65 (Ação Popular) e 17, caput e $\$ 3^{\circ}$ da Lei n. 8.429/92 (Improbidade Administrativa), tal como a sua legitimidade para a ação de improbidade administrativa e

${ }^{64}$ É a interpretação que se extrai, por exemplo, dos arts. 21 e 22 da CRFB, quando tratam da competência legislativa da União. 
demais ações coletivas (art. $5^{\circ}$ da Lei n. 7.347/85), razão não há para negar essa atuação em prol dos direitos transindividuais.

Crimes praticados contra as relações de consumo, crimes ambientais e o tráfico ilícito de entorpecentes, por exemplo, poderão ser tutelados pela Fazenda Pública ou pela Defensoria Pública quando evidenciada a omissão do Ministério Público.

Que fique claro, no entanto, que Defensoria Pública e Fazenda Pública só atuarão em caráter supletivo, jamais invadindo as esferas de atribuição do Ministério Público no sistema penal.

O Ministério Público é o representante primário da sociedade na defesa da ordem jurídica e da persecução penal por escolha de nosso constituinte. Ao seu lado erigem-se a Defensoria Pública como uma instituição de defesa de direitos humanos e dos direitos transindividuais e a Fazenda Pública com o papel de salvaguarda de interesses da coletividade, sempre que houver uma proteção deficiente dos bens jurídicos.

\section{Conclusão}

O objetivo do presente estudo é apenas o de suprir uma importante lacuna criada pelo processo penal brasileiro diante dos inúmeros avanços e reflexões traçadas na doutrina processual e no Direito Penal em matéria de defesa de bens jurídicos penais transindividuais.

Na conclusão desta breve reflexão percebemos que a adequada tutela dos direitos humanos e transindividuais na seara penal passa ao largo da solitária e penosa iniciativa do Ministério Público. Apesar de muitos ainda não enxergarem uma legitimidade supletiva da ação penal pública por parte de outros órgãos e instituições estatais, está ela ali para quem quiser reconhecê-la.

Em matéria de proteção de direitos individuais e coletivos, quanto mais legitimados maior a proteção daqueles direitos - argumento utilizado para ampliação de legitimação para a tutela coletiva ${ }^{65}$.

65 “1) O objetivo do Ministério Público ao visar a supressão da legitimidade da Defensoria Pública é o de evitar a concorrência da instituição na tutela coletiva. 2) A Constituição Federal não prevê a exclusividade do Ministério Público para o ajuizamento da Ação Civil Pública, ao que se depreende do art. 129, § $1^{\circ}$, da CRFB. Em verdade, a ampliação do rol de legitimados apenas serve como soma 
O Código de Defesa do Consumidor e a legislação nacional da própria Defensoria Pública lhe permitem exercer a iniciativa da ação penal publica em matéria de direitos transindividuais em caso de inércia parquet.

A legitimidade supletiva tem lugar muito bem delineado, como apontamos neste estudo, e as discussões de caráter corporativo não são capazes de romper o modelo de defesa penal dos bens jurídicos difusos e coletivos.

De igual modo, os órgãos integrantes das pessoas jurídicas de direitos público precisam melhor digerir esse papel de proteção. $\mathrm{O}$ Estado deve ser capaz de romper o seu perfil de violador de direitos e exercer o propósito pelo qual foi criado, o de proporcionar a adequada e correta vida em sociedade.

Advirta-se apenas neste momento final que o objetivo deste estudo não é o de tornar ampla a legitimação da ação penal pública. O que pretendemos aqui foi preservar a titularidade da ação penal pública nas mãos do Ministério Público e, ao mesmo tempo, assegurar uma eficaz proteção de bens jurídicos no caso de inércia do parquet.

\section{REFERÊNCIAS}

AVENA, Norberto. Processo penal esquematizado. 4. Ed. São Paulo: Método. 2012. BADARÓ, Gustavo Henrique. Correlação entre acusação e sentença. São Paulo: RT, 2000.

de forças, permitindo que outra instituição também possa tutelar os interesses difusos. 3) A ampliação do rol de legitimados é apenas reflexo do movimento de crescente ampliação e facilitação do acesso à justiça. 4) A Constituição Federal no art. 134 não estabeleceu limites às atribuições da Defensoria Pública. A orientação jurídica e defesa dos necessitados é apenas uma das funções, sendo certo que a legislação pode estabelecer outras mais. 5) A interpretação do termo "necessitado" merece nova reflexão de modo a alcançar não apenas os hipossuficientes do ponto de vista econômico. A necessidade também é sinônimo de vulnerabilidade, de estrutura organizacional. 6) Muito antes da alteração da Lei de Ação Civil Pública a Defensoria Pública já atuava na tutela de interesses difusos, diante do permissivo constante do Código de Defesa do Consumidor.” (GRINOVER, Ada Pellegrini. Parecer a respeito da constitucionalidade da Lei $\mathrm{n}^{\circ}$ 11.448/2007, que conferiu legitimidade ampla à Defensoria Pública para a ação civil pública. In: SOUSA, José Augusto Garcia de. Uma nova Defensoria Pública pede passagem, Rio de Janeiro: Lumen Juris, 2011, p. 473-491). 
BECHARA, Ana Elisa Liberatore S. O rendimento da teoria do bem jurídico no direito penal atual. Revista Liberdades. São Paulo: IBCCRIM. N. 01, mai-ago, 2009. BOSON, Erick Palácio. A defensoria pública e a tutela jurisdicional da moralidade administrativa. Salvador: Juspodivm, 2016.

CABRAL, Antonio do Passo. Nulidades no processo moderno. Rio de Janeiro: Forense, 2009.

CADIET, Loïc. Prolégomènes à une théorie générale du procès en droit français. In DIDIER JR., Fredie; JORDÃO, Eduardo Ferreira (Org.). Teoria do processo: panorama doutrinário mundial. Salvador: Juspodivm, 2008.

CASSEL, Doug.International human rightslawand securitydetention. Disponívelem http://scholarship.law.nd.edu/cgi/viewcontent.cgi?article=1681\&context=law_ faculty_scholarship. Acesso em 29 set 2016.

COSTA, Renata Tavares da. Os direitos humanos como limite ético na defesa dos acusados de feminicídio no tribunal do júri. Livro de Teses e Práticas Exitosas. ANADEP: Paraná, 2015.

CÂMARA, Alexandre Freitas. A fase preliminar do procedimento da ação de improbidade administrativa. Disponível em: https://www.academia. edu/375133/A_fase_preliminar_do_procedimento_da_ação_de_ improbidade_administrativa_Acesso em: 13 jun 2016.

CARVALHO, Paula Marques. Manual prático de processo penal. 8. Ed. Almedina: Coimbra, 2014.

COMPAREID, Carlos Roman; SANTAGATI, Claudio Jesús. Manual de derecho procesal penal. Buenos Aires: Ediciones Juridicas, 2010.

DANTAS JUNIOR, Genival Torres. A tutela da vítima pela defensoria pública na persecução penal. Rio de Janeiro: Lumen Juris, 2016.

DIDIER JR., Fredie. Sobre a teoria geral do processo, essa desconhecida. 3.ed. Salvador: Juspodivm, 2016.

DIVAN, Gabriel Antinolfi. Processo penal e política criminal: uma reconfiguração da justa causa para a ação penal. Porto Alegre: Elegantia Juris, 2015.

ESTEVES, Diogo; SILVA, Franklyn Roger Alves. Princípios institucionais da defensoria pública. Rio de Janeiro: Forense, 2014.

GARCIA, Emerson. Ministério público: organização, atribuições e regime jurídico. 4. Ed. São Paulo: Saraiva, 2014.

GRECO, Leonardo. Instituições de processo civil. 5. Ed. Rio de Janeiro: Forense, 2015. GRINOVER, Ada Pellegrini. Parecer a respeito da constitucionalidade da Lei ${ }^{\circ}$ 11.448/2007, que conferiu legitimidade ampla à Defensoria Pública para a ação 
civil pública. In SOUSA, José Augusto Garcia de. Uma nova Defensoria Pública pede passagem, Rio de Janeiro: Lumen Juris, 2011.

JARDIM, Afrânio Silva. A originalidade como condição para o regular exercício do direito de ação. Revista Eletrônica de Direito Processual, Rio de Janeiro, vol. 15, n. 15, 2015. http://dx.doi.org/10.12957/redp.2015.16860

JARDIM, Afrânio Silva; AMORIM, Pierre Souto Maior Coutinho de. Direito processual penal: estudos e pareceres. 14. Ed. Salvador: Juspodivm, 2016.

JESUS, Damásio E. Direito Penal. Vol. I. 28. Ed. São Paulo: Saraiva, 2005.

JUNQUEIRA, Gustavo; ZVEIBEL, Daniel G; REIS, Gustavo Augusto Soares. Comentários à lei da defensoria pública. São Paulo: Saraiva, 2014.

LIMA, Frederico Rodrigues Viana de. Defensoria pública. Salvador: Juspodivm, 2015.

LOPES JR., Aury. Direito processual penal. 11. Ed. São Paulo: Saraiva, 2014.

MARQUES, José Frederico. Elementos de direito processual penal. Campinas: Bookseller, 1998. Vol. I.

MARQUES, José Frederico. Manual de direito processual civil. Campinas: Bookseller, 1997. Vol. I.

MARQUES, Karla Padilha Rebelo. Implicações penais e processuais penais da defensoria pública. In ANTUNES, Maria João et al. Novos atores da justiça penal. Coimbra: Almedina, 2016.

MAZZUOLI, Valerio de Oliveira. O controle jurisdicional da convencionalidade das leis. 3. Ed. São Paulo: RT, 2013.

PAIVA, Caio. Prática penal para defensoria pública. Rio de Janeiro: Forense, 2016.

SANTOS, Juarez Cirino dos. Direito penal: parte geral. 2. Ed. Rio de Janeiro: Lumen Juris, 2007.

SICA, Heitor Vitor Mendonça. Perspectivas atuais da teoria geral do processo. In CARNEIRO, Athos Gusmão; CALMON, Petrônio (Org). Bases científicas para um renovado direito processual. Brasília: IBDP, 2008. V. 1.

SILVA, Franklyn Roger Alves. A nova formatação constitucional da defensoria pública à luz da emenda constitucional n. 80/14. http://www.cursocei.com/ reflexos-da-ec-n-80-de-2014/Acesso em 13 mai. 2016.

SILVA, Franklyn Roger Alves. Os efeitos do novo código de processo civil no direito processual penal: um feixe de luz para o caminho da sofisticação ou a permanência na escuridão? Revista Forense, Rio de Janeiro, vol. 423, 2016.

SOUSA, José Augusto Garcia de. A nova lei 11.448/07, os escopos extrajurídicos do processo e a velha legitimidade da defensoria pública para ações coletivas. In 
SOUSA, José Augusto Garcia de. A defensoria pública e os processos coletivos. Rio de Janeiro: Lumen Juris, 2008.

SOUSA, José Augusto Garcia de. O destino de Gaia e as funções constitucionais da Defensoria Pública: ainda faz sentido - sobretudo após a edição da Lei Complementar 132/2009 - a visão individualista a respeito da instituição? In Uma nova Defensoria Pública pede passagem, Rio de Janeiro: Lumen Juris, 2011.

TAVARES, Juarez. Teoria do injusto penal. 3. Ed. Belo Horizonte: Del Rey. 2003.

TONINI, Paolo. Manuale di procedura penale. Milano: Giuffrè. 2009.

TORNAGHI, Helio. Instituições de processo penal. Rio de Janeiro: Forense, 1959. Vol. III.

TOURINHO FILHO, Fernando da Costa. Processo Penal. 29. Ed. São Paulo: Saraiva, 2007.

WEISS, Carlos. Os direitos humanos e os interesses transindividuais. Disponível em: http://www.pge.sp.gov.br/centrodeestudos/bibliotecavirtual/Congresso/ xtese3.htm Acesso em: 13 jun 2016.

\section{Dados do processo editorial}

(http://www.ibraspp.com.br/revista/index.php/RBDPP/about/editorialPolicies)

- Recebido em: $12 / 09 / 2016$ Equipe editorial envolvida

- Controle preliminar e verificação de plágio: 13/09/2016

- Avaliação 1: 16/09/2016

- Avaliação 2: 19/09/2016

- Editor-chefe: 1 (VGV)

- Editor-associado: 1 (AMM)

- Revisores: 2

- Decisão editorial preliminar: 20/09/2016

- Retorno rodada de correções 1:09/10/2016

- Decisão editorial final: 10/10/2016

\section{COMO CITAR ESTE ARTIGO:}

SILVA, Franklyn R. A. Legitimação Não Tradicional da Ação Penal - A Tutela de Bens Jurídicos por Outras Instituições Públicas. Revista Brasileira de Direito Processual Penal, Porto Alegre, vol. 3, n. 1, p. 367-404, jan./abr. 2017. https://doi.org/10.22197/rbdpp.v3i1.27

Esta obra está licenciada com uma Licença Creative Commons Atribuição-NãoComercial 4.0 Internacional. 